\title{
Prevalence and factors associated with malnutrition in children aged 6-59 months in Jubek State, South Sudan.
}

Martin Adelino lyya ( $\nabla$ ohureomoi@gmail.com )

Makerere University https://orcid.org/0000-0001-9674-5506

Ndeezi Grace

Makerere University College of HealthSciences School of Medicine

Nabukeera Barungi Nicolette

Makerere University College of Health Sciences

Hassan Chollong

University of Juba

Research article

Keywords: Malnutrition, Stunting, factors associated, wasting, underweight, South Sudan, Jubek State

Posted Date: December 7th, 2020

DOl: https://doi.org/10.21203/rs.3.rs-15585/v3

License: (c) (i) This work is licensed under a Creative Commons Attribution 4.0 International License.

Read Full License 


\section{Abstract}

Background: South Sudan is the world's youngest nation which gained independence from Sudan on the 9th of July, 2011. Rates of acute malnutrition have been consistently higher in South Sudan than any other country in sub-Saharan Africa, according to South Sudan Household Survey 2010, the prevalence of Global Acute Malnutrition in children under 5 years was $22 \%$, Prevalence of stunting is $45 \%$ and underweight was $48 \%$. This study sought to determine the prevalence and factors associated with malnutrition among children aged 6-59 months in Jubek state, South Sudan.

Methods: This was a cross sectional analytical community based study to assess the prevalence and factors associated with malnutrition among children aged 6-59 months in Jubek state, South Sudan. Data was collected using a structured questionnaire from 396 children. Anthropometric measurements including weight, length/ height, mid upper arm circumference (MUAC) were taken and a blood sample by finger prick was removed for HIV test. The equipment which were used included: WHO recommended MUAC tape for 6 months to 59 months old children, digital weighing scale (SECA) and portable Stadiometers. Data were collected using a pretested semi- structured questionnaire.

Results: The analysis of this study revealed that, $32.2 \%, 28.2 \%$ and $32.3 \%$ of children were stunted, wasted and underweight respectively. The main associated factors of stunting were age older than one year $(p=0.004)$, children from households who were renting their houses and children who defecate in open spaces with no latrine at their homes $(p=0.015)$. Underweight was associated with child's age $(p=$ $0.001)$, loss of appetite $(p=<0.001)$, children who ate from own plate $(p=0.001)$ and children who didn't consume meat $(p=0.007)$. Male genders $(p=0.022)$, households with two or more children aged zero to five years $(0.010)$ not consuming vitamin A rich vegetable $(p=0.002)$, diarrheal disease within two weeks prior to interview $(p=0.006)$ and those from households with water sources other than piped $(<0.001)$ were also associated with wasting.

Conclusion: The general objective of this study was to assess the nutritional status of children aged 6-59 months in Jubek state, South Sudan. This study showed that the levels of stunting, wasting and underweight were high, one in three children were likely to be stunted $(32.1 \%)$, or wasted $(28.2 \%)$ or underweight (32.3\%).

\section{Background}

Malnutrition is estimated to contribute to more than one third of all child deaths. Lack of access to highly nutritious foods, especially in the present context of rising food prices, is a common cause of malnutrition. Poor feeding practices, such as inadequate breastfeeding, offering the wrong foods, and not ensuring that the child gets enough nutritious food, contribute to malnutrition. Infection - particularly frequent or persistent diarrhea, pneumonia, measles and malaria - also undermines a child's nutritional status (1). 
In the year 2011, 6.9 million children under the age of 5 years died worldwide, one third of them related to increased susceptibility to illnesses due to under nutrition. An estimated 178 million children under 5 years are stunted, 55 million are wasted, and 19 million of these are severely affected and are at a higher risk of premature death, the vast majority being from sub-Saharan Africa and South-Central Asia (2).

Post war areas in the East African region have reported high levels of malnutrition. The level of global acute malnutrition in Gulu district in Uganda was $6.0 \%$, prevalence of global stunting was found to be $52.4 \%$, this was similar to another post war area in Kasese district in Uganda which also found a prevalence of $49.8 \%$ (3) (4).

South Sudan is underdeveloped country with very little basic infrastructure for health systems, safe water, functioning markets and lack of food security.

Reports from WHO and UNICEF in 2013, under five years mortality rate is $65 \%$ in which neonatal mortality accounts for $35 \%$ (5). UNICEF South Sudan described the nutrition situation for children in the country as dire, with over 248,000 children estimated to be suffering from severe acute malnutrition (SAM). This number rose from 108,000 before the 2013 crisis to 248,000 in 2015 mainly due to deteriorating food insecurity, displacement and destruction of health, water sanitation facilities along with suboptimal infant and young child feeding practice (IYCF) (6).

This study aimed to determine the prevalence and factors associated with malnutrition among children aged under five years in Jubek state, South Sudan.

Jubek state was chosen because of increase population secondary to influx of internally displaced people, cultural diversity and more secured compared to other states within South Sudan.

\section{Methods}

\section{Study area}

This study was carried out in Jubek State located in the Southern part of South Sudan. The state borders include Yei River State to the south east, Amadi State to the west, Terekeka State to the north and Imatong State to the east(7). In 2008, Jubek State had a population of about 1.1 million people with 581, 722 males and 521,835 females. Children under the age 18 constitute $49 \%$ with $15 \%$ of the population being children under the age of 5 years. It is an urban state where South Sudan's capital city Juba is located. It has an area of 43,033 square kilometers.

Jubek State is consisted of 14 counties. Theses counties are further divided into Payams, then Bomas. Juba is known as the capital of the entire country as well as the capital of Jubek State.

\section{Selection of subjects:}


The study population including all children aged 6-59 months was randomly selected. All children aged 659 months in Jubek State during the study period. Children whose parents/ Caregivers provided written informed consent

We employed the modified WHO cluster sampling technique to select study households and participants. Households with more than one child aged of 6-59 months were assigned numbers on a dice from the youngest to oldest by the principal investigator/or research assistant. The research assistant/ Principal investigator would then roll the dice and the child selected for the interview would be the one whose number corresponds to the dice number facing upwards after the roll.

\section{Sample size and sampling technique}

The sample size calculation for this study was based on (i) the prevalence of malnutrition with a design effect (DEFF) adjustment because the sampling design used was cluster sampling rather than simple random sampling, and (ii) association between malnutrition and selected factors, like consumption of safe drinking. The higher computed size of 396 from the two options was chosen as the study sample size.

\section{Variables:}

The primary outcome of this study was nutritional status measured by stunting because it is a variable that measures chronic malnutrition and long term outcomes. Whereas the secondary outcomes were both wasting and underweight.

The independent variables for this study included: socio-demographic variables, child characteristics; child caring practices, and environmental health. Information on these independent variables was collected using a pretested structured questionnaire administered on caretakers of 396 children. Children were Weighted with minimum clothing, bare feet using a digital SECA scale in kilogram to the nearest of $0.1 \mathrm{~kg}$. whereas their length was taken in a lying position with wooden measuring height board for children aged less than two years. The height of children aged more than two years was measured in a standing position in centimeters to the nearest of $1 \mathrm{~cm}$. Information for anthropometric measurements were collected through measuring of length/height and weight of the selected participants. WHO growth charts (2006) were used to convert the anthropometric measures into Z-scores of the indices; Height for Age(HAZ), Weight-for-Height(WHZ) and Weight-for Age(WAZ).

\section{Measurements for the disease burden}

Questionnaire was used to capture information on the disease burden. Questions on presence of any chronic illness including T.B, HIV, or history of recent diarrhea, fever, and ARI were asked to assess for the disease burden.

Blood samples for HIV testing were taken for children whose primary care giver consented. We used rapid ELISA test. This HIV testing was done by the research assistant/ counselor who received training in 
counseling and how to perform HIV test. Children found to be HIV positive were linked to AL-Sabah Children's hospital which provides HIV services.

\section{Measurement for household food security}

This was assessed using Household Food Insecurity Access Scale (HFIAS) which assess three domains in the household includes: uncertainty about household access and anxiety, insufficient quality and quantity of food intake (8)

Questions 24- hour recall on the number, type of foods taken was used to measure for the household food diversity and frequency.

\section{Analysis}

STATA 14.2 statistical software was done for Statistical analyses. we first analyzed the descriptive statistics including proportions and frequencies in tables. This was then followed by the bivariate analyses of the three outcome indicators of malnutrition (stunting, wasting and underweight) each separately. All variable (independent) in the bivariate analyses with a p-value less than 0.25 were preliminarily taken for further analyses and diagnostic testing in multivariate analyses. Bivariate and modeling was done using a logistic modeling to produce both unadjusted and adjusted odds ratios and their corresponding p-values. Backward elimination technique in logistic modeling was used to identify the determinants of the three outcomes of malnutrition (wasting, stunting and underweight). Statistical significance was observed where $p<0.05 t$ as statistical measure of association.

\section{Ethics Approval and consent to participate}

Permission to carry the study was obtained from the department of pediatrics and child health, Federal ministry of health South Sudan, Jubek's state ministry of health and permission from the local community leaders to carry this study was also sought. Ethics approval was obtained from the Makerere University School of Medicine Research and Ethics Committee (SOMREC) as well as the Uganda National Council of Science and Technology. A written informed consent/assent was sought from the caregiver followed by a full explanation of the study objectives, procedures, risks and benefits. Care givers were also informed that they had rights to participate and withdraw out of the study at any time.

Children who were found to be undernourished, were linked to appropriate therapeutic facility.

\section{Results}

out of the total of 396 sampled and interviewed study participants, only 393 (99.2\%) were analyzed , 3(Three) withdrew their consent during the interview process. Socio Demographic of the sampled children, their caretakers and their households are presented in Table 1. A total of 393 children aged 6-59 months in Jubek State were enrolled in the study. There were almost equal numbers of males and females in the ratio of 1:1. Eighty-eight percent of the participants were Christians (349/393), and most of 
the respondents were mothers $(355 / 393,90.3 \%)$. Only $86(21.9 \%)$ households had five or less members and $161(40.9 \%)$ of the households had ten or more members. As regards to the economic status of the caretakers, most of the caretakers were earning more than 1USD (18ssp) per day and only 21/393 (7.8\%) were earning less than 1USD (18ssp) per day. Other socio demographics of the children are shown in Table 1. 


\section{Table 1: Demographic factors of children aged 6-59 months and caretakers in Jubek State enrolled study}

Characteristic

Total $n$

(\%)

$\begin{array}{ll}\text { Sex of Child } & \text { Male } \\ & \text { Female } \\ \text { Age of Child } & <12 \text { Months } \\ & \geq 12 \text { Months } \\ \text { Religion of child } & \text { Christian } \\ & \text { Others }\end{array}$

$199(50.6)$

$194(49.4)$

$51(13.0)$

$342(87.0)$

$349(88.8)$

Respondent's details

Age of respondent

Relationship to child

Marital Status of Caretaker

Level of Education

Mother to child

Father to child $\leq 24$ Years

25 and above

Mother

Father

Others

Single

Married

Cohabiting

Widowed

No Formal Education

Primary

Secondary\& above

No Formal Education

Primary

Secondary\& above

Education

Socio-economic characteristics

Monthly income of caretaker to child

Building type

House ownership

Farmland

Household number of people

Household members aged 0-5yrs

$\mathrm{HH}$ members aged 6-18 years

yyarsyears Years

$>10$ Members
Below 500ssps

500-1000ssp

$21(7.8)$

1000-5000sspssp

Above 5000ssp

Mud

Bricks

Rented

Owned

Yes

No

$\geq 10$ Members

$\leq 2$ Members

$>2$ Members

$\leq 4$ Member

$<4$ Members

$134(49.8)$

$75(27.9)$

$317(83.4)$

$63(16.6)$

$193(49.1)$

$200(50.9)$

35(9.3)

345 (90.7)

$232(59.0)$

$161(41.0)$

251 (63.9)

$142(36.1)$

$342(87.0)$

$51(13.0)$
$110(28.0)$

283(72.2)

355(90.3)

23(5.9)

15(3.8)

$3(0.8)$

341 (86.8)

$31(7.9)$

18(4.6)

$113(28.8)$

$148(37.7)$

$132(33.6)$

$45(12.2)$

$61(16.5)$

263(71.2)

Among children enrolled in this study, most 328(83.5\%) were fully immunized, but 65(16.5\%) children were not/partially immunized (Table 2). Over four tenth $174(44.3 \%$ ) of the children had ever been 
diagnosed with pneumonia whereas 13(3.3\%) had ever been diagnosed with measles. Other health related conditions assessed in this study are shown in Table 2.

Table 2: Medical history and clinical characteristics of the participant

\begin{tabular}{llr}
\hline Factor & & TOTAL n (\%) \\
\hline Immunization Status of Child & Fully Immunized & $328(83.5)$ \\
\hline & Not Immunized & $65(16.5)$ \\
\hline Child sleep under mosquito net & & $343(87.3)$ \\
\hline & Yes & $50(12.7)$ \\
\hline Been diagnosed with: & No & $174(44.3)$ \\
\hline i) Pneumonia & Yes & $219(55.7)$ \\
\hline & No & $13(3.3)$ \\
\hline iii) Measles & Yes & $380(96.7)$ \\
\hline & No & $4(1.0)$ \\
\hline iv) HIV & Yes & $389(99.0)$ \\
\hline Illness in the past two weeks & No & \\
\hline & & $171(43.5)$ \\
\hline i) Cough & No & $222(56.5)$ \\
\hline & Yes & $325(82.7)$ \\
\hline iii)Vomiting & No & $68(17.3)$ \\
& Yes & $246(62.6)$ \\
\hline iv) Loss of Appetite & No & $147(37.4)$ \\
\hline v) Diarrhea & Yes & $274(69.7)$ \\
\hline & No & $119(30.3)$ \\
\hline vi) Fever & Yes & $205(52.2)$ \\
\hline & No & $188(47.8)$ \\
\hline
\end{tabular}

Regarding food security, only $33(8.4 \%)$ of the sampled households were food secure and the rest, $91.6 \%$, were food insecure with; $11(2.8 \%)$ mildly food insecure, $47(12.0 \%)$ moderately food insecure and the biggest percentage, $76.8 \%$ of the households were severely food insecure table 7 .

Among the children enrolled in the study, over half were exclusively breastfed $218(55.5 \%)$. For most of the children, other food was introduced after six months $214(54.4 \%)$. Majority of the children were reported to be eating from their own plate $237(60.3 \%)$ whereas $156(39.7 \%)$ were eating from a family pot. Soup 199(50.6\%) and porridge 162(41.2\%) were the major first foods introduced to children at 6 months. Majority $348(88.6 \%)$ of the children feed less than 5 times a day, with only $45(11.4 \%)$ feeding more than 4 times a day (Table 3 ). 
Table 3: Nutrition and Feeding History Characteristics

\begin{tabular}{lll}
\hline Factors & & TOTAL $\mathbf{n}$ (\%) \\
\hline Exclusively Breastfed for 6 months & Yes & $218(55.5)$ \\
& No & $146(37.2)$ \\
& Non-Response & $29(7.4)$ \\
\hline & & \\
\hline At what age was other food Introduced & Less than 6 Months & $179(45.6)$ \\
& After 6 Months & $214(54.4)$ \\
\hline & & \\
\hline Does this Child Eat From & Family Pot & $156(39.7)$ \\
\hline & Own Plate & $237(60.3)$ \\
\hline Food First Introduced at 6 Months & Porridge & $162(41.2)$ \\
\hline & Soup & $199(50.6)$ \\
\hline & Milk & $27(6.9)$ \\
\hline Number of Times the Child Feeds & Others & $5(1.3)$ \\
\hline & $<5$ Times/Day & $348(88.6)$ \\
\hline & $\geq 5$ Times/Day & $45(11.4)$ \\
\hline
\end{tabular}

\section{Prevalence of Malnutrition}

Of the children enrolled in the study, $126 / 393$ (32.1\%; $95 \% \mathrm{Cl}$ : $27.5 \%-36.9 \%)$ were stunted, $111 / 393$ (28.2\%; 95\% Cl: 23.8\% - 33.0\%) were wasted and 127/393 (32.3\%; 95\% Cl: 27.7\% - 37.2\%)were underweight Figure (1). The prevalence for a child being any one of: stunted, wasted, or underweight was 197/393 (50.1\%; 95\% Cl: 45.1\% - 55.2\%).

\section{Factors associated with Malnutrition}

The multivariate analyses for wasting are shown in Table4. Females were less likely to be wasted $(A O R=0.56,95 \% \mathrm{Cl}: 0.35-0.92, p=0.022)$ whereas children diagnosed with diarrhea were twice likely to be wasted (AOR=2.03, 95\% Cl: 1.22-3.36) Table (4). 
Table 4: Multivariable analyses for factors associated with Wasting

\section{Factor}

Adjusted Odds P-value Ratio

$(95 \% \mathrm{CI})$

Sex of Child

$\begin{array}{lll}<2 \text { Members } & 1.00 & \\ >2 \text { Members } & 7.63(1.27-5.48) & \mathbf{0 . 0 1 0}\end{array}$

Number of household members between 0-

Male $\quad 1.00$

$\begin{array}{lll}\text { Female } & 0.56(0.35-0.92) & \mathbf{0 . 0 2 2}\end{array}$

5 Years

Water Source

Piped Water

1.00

Other Water

$3.02(1.74-5.25)$

$<0.001$

Sources

Diarrhoea

\begin{tabular}{llll}
\hline & No & 1.00 & \\
\hline & Yes & $2.03(1.22-3.36)$ & $\mathbf{0 . 0 0 6}$ \\
$\begin{array}{l}\text { Consume Vitamin A Rich Vegetables \& } \\
\text { Tubers }\end{array}$ & Yes & 1.00 & \\
\hline & No & $2.22(1.35-3.65)$ & $\mathbf{0 . 0 0 2}$ \\
\hline
\end{tabular}

\section{Factors associated with underweight}

The multivariate analyses for the underweight model are shown in Table 5. Children aged older than one year were observed to be more than twice likely to be underweight whereas ( $A O R=4.29,95 \% \mathrm{Cl}: 1.87-9.83$, $\mathrm{p}=0.0001)$. 
Table 5: Multivariable analyses for factors associated with Underweight

\begin{tabular}{|c|c|c|c|}
\hline Factor & & $\begin{array}{c}\text { Adjusted Odds Ratio } \\
(95 \% \mathrm{CI})\end{array}$ & P-value \\
\hline \multirow[t]{3}{*}{ Age of Child } & $<12$ Months & 1.00 & \\
\hline & $\geq 12$ Months & $4.29(1.87-9.83)$ & 0.001 \\
\hline & No & 1.00 & \\
\hline Loss of Appetite & Yes & $2.66(1.62-4.37)$ & $<0.001$ \\
\hline \multirow[t]{2}{*}{ Child's Eating Place } & Family Pot & 1.00 & \\
\hline & Own Plate & $2.51(1.48-4.27)$ & 0.001 \\
\hline \multirow[t]{3}{*}{ Carer of Sick Child } & Mother & 1.00 & \\
\hline & Father & $0.42(0.14-1.29)$ & 0.128 \\
\hline & Grandmother & $0.16(0.04-0.59)$ & 0.006 \\
\hline \multirow{2}{*}{$\begin{array}{l}\text { Consume Vitamin A Rich Vegetables \& } \\
\text { Tubers }\end{array}$} & Yes & 1.00 & \\
\hline & No & $2.98(1.78-5.02)$ & $<0.001$ \\
\hline \multirow[t]{2}{*}{ Consume Organ Meat } & Yes & 1.00 & \\
\hline & No & $2.17(1.24-3.81)$ & 0.007 \\
\hline
\end{tabular}


Socio demographic and economic factors associated with Stunting

\begin{tabular}{|c|c|c|c|c|c|c|c|c|}
\hline & & $\begin{array}{l}\text { TOTAL } \\
\text { n (\%) }\end{array}$ & $\begin{array}{c}\text { Stunted } \\
\text { n (\%) }\end{array}$ & $\begin{array}{c}\text { Not } \\
\text { Stunted } \\
\mathrm{n}(\%)\end{array}$ & $\begin{array}{l}\text { Unadjusted- } \\
\text { odds ratio } \\
\text { (95\% CI) }\end{array}$ & $\begin{array}{l}\mathrm{P} \\
\text { value }\end{array}$ & $\begin{array}{l}\text { Adjusted- } \\
\text { odds ratio } \\
(95 \% \mathrm{CI})\end{array}$ & $\begin{array}{l}\mathrm{P} \\
\text { value }\end{array}$ \\
\hline & $<12$ & $51(13.0)$ & $7(13.7)$ & $44(86.3)$ & 1.00 & & 1.00 & \\
\hline & $\begin{array}{l}\geq 12 \\
\text { Months }\end{array}$ & $342(87.0)$ & $119(34.8)$ & $223(65.2)$ & $\begin{array}{l}3.35(1.47- \\
7.68)\end{array}$ & 0.004 & $\begin{array}{l}4.43(1.86- \\
10.56)\end{array}$ & 0.001 \\
\hline & Male & 199(50.6) & 71(35.7) & $128(64.3)$ & 1.00 & & 1.00 & \\
\hline & Female & 194(49.4) & $55(28.4)$ & $139(71.6)$ & $\begin{array}{l}0.71(0.47- \\
1.09)\end{array}$ & 0.12 & $\begin{array}{l}0.72(0.45- \\
1.15)\end{array}$ & 0.168 \\
\hline of & Christian & $349(88.8)$ & $116(33.2)$ & 233(66.8) & 1.00 & & 1.00 & \\
\hline & Others & $44(11.2)$ & $10(22.7)$ & $34(77.3)$ & $\begin{array}{l}0.59(0.28- \\
1.24)\end{array}$ & 0.163 & $\begin{array}{l}0.52(0.24- \\
1.15)\end{array}$ & 0.108 \\
\hline ; & $\begin{array}{l}\text { Family } \\
\text { pot }\end{array}$ & $156(39.7)$ & $31(19.9)$ & $125(80.1)$ & 1.00 & & & \\
\hline & $\begin{array}{l}\text { Own } \\
\text { plate }\end{array}$ & $237(60.3)$ & $95(40.1)$ & $142(59.9)$ & $\begin{array}{l}2.70(1.68- \\
4.32)\end{array}$ & $<0.001$ & $\begin{array}{l}2.71(1.67- \\
4.4)\end{array}$ & 0.000 \\
\hline & Mud & $330(84.0)$ & $105(31.8)$ & $225(68.2)$ & 1.00 & & 1.00 & \\
\hline & Bricks & $63(16.0)$ & $21(33.3)$ & $42(66.7)$ & $\begin{array}{l}1.07(0.60- \\
1.90)\end{array}$ & 0.813 & $\begin{array}{l}1.44(0.74- \\
2.81)\end{array}$ & 0.278 \\
\hline ip & Rented & $193(49.1)$ & $81(42.0)$ & $112(58.0)$ & 1.00 & & 1.00 & \\
\hline & Owned & $200(50.9)$ & $45(22.5)$ & $155(77.5)$ & $\begin{array}{l}0.40(0.26- \\
0.62)\end{array}$ & $<0.00$ & $\begin{array}{l}0.4(0.25- \\
0.64)\end{array}$ & 0.000 \\
\hline l & Yes & $35(9.3)$ & $8(22.9)$ & $27(77.1)$ & 1.00 & & 1.00 & \\
\hline & No & $246(62.6)$ & $67(27.2)$ & $179(72.8)$ & 1.00 & & 1.00 & \\
\hline & Yes & $147(37.4)$ & $59(40.1)$ & $88(59.9)$ & $\begin{array}{l}1.79(1.16- \\
2.76)\end{array}$ & 0.008 & $\begin{array}{l}1.81(1.09- \\
3.02)\end{array}$ & 0.022 \\
\hline & $\begin{array}{l}\text { Flash } \\
\text { Toilet }\end{array}$ & $19(4.8)$ & $4(21.1)$ & $15(78.9)$ & 1.00 & & 1.00 & \\
\hline & $\begin{array}{l}\text { Open } \\
\text { Spaces }\end{array}$ & $24(6.1)$ & $14(58.3)$ & $10(41.7)$ & $\begin{array}{l}5.25(1.33- \\
20.65)\end{array}$ & 0.018 & $\begin{array}{l}0.31(0.12- \\
0.8)\end{array}$ & 0.008 \\
\hline & $\begin{array}{l}\text { Pit } \\
\text { Latrine }\end{array}$ & $338(86.0)$ & $105(31.1)$ & $233(68.9)$ & $\begin{array}{l}1.69(0.55- \\
5.21)\end{array}$ & 0.361 & $\begin{array}{l}0.15(0.03- \\
0.7)\end{array}$ & 0.016 \\
\hline
\end{tabular}


Iousehold food security with Stunting

\begin{tabular}{|c|c|c|c|c|c|c|c|}
\hline & $\begin{array}{l}\text { TOTAL } \\
\text { n (\%) }\end{array}$ & $\begin{array}{c}\text { Stunted } \\
\text { n (\%) }\end{array}$ & $\begin{array}{c}\text { Not } \\
\text { Stunted } \\
\mathrm{n}(\%)\end{array}$ & $\begin{array}{l}\text { Unadjusted- } \\
\text { odds ratio } \\
\text { (95\% CI) }\end{array}$ & $\begin{array}{l}\text { P } \\
\text { value }\end{array}$ & $\begin{array}{l}\text { Adjusted- } \\
\text { odds ratio } \\
\text { (95\% CI) }\end{array}$ & $\begin{array}{l}P \\
\text { value }\end{array}$ \\
\hline $\begin{array}{l}\text { Food } \\
\text { Secure }\end{array}$ & $33(8.4 \%)$ & $12(36.4)$ & $21(63.6)$ & 1.00 & & 1.00 & \\
\hline $\begin{array}{l}\text { Mildly } \\
\text { Food } \\
\text { Insecure }\end{array}$ & $11(2.8 \%)$ & $1(9.1)$ & $10(90.9)$ & $\begin{array}{l}0.18(0.02- \\
1.54)\end{array}$ & 0.116 & $\begin{array}{l}0.21(0.02- \\
2.13)\end{array}$ & 0.188 \\
\hline $\begin{array}{l}\text { Moderately } \\
\text { Food } \\
\text { Insecure }\end{array}$ & $47(12.0 \%)$ & $14(29.8)$ & $33(70.2)$ & $\begin{array}{l}0.74(0.29- \\
1.91)\end{array}$ & 0.537 & $\begin{array}{l}0.44(0.06- \\
3.19)\end{array}$ & 0.415 \\
\hline $\begin{array}{l}\text { Severely } \\
\text { Food } \\
\text { Insecure }\end{array}$ & $302(76.8 \%)$ & $99(32.8)$ & $203(67.2)$ & $\begin{array}{l}0.85(0.40- \\
1.80)\end{array}$ & 0.678 & $\begin{array}{l}0.19(0.02- \\
1.55)\end{array}$ & 0.123 \\
\hline No & $83(21.1)$ & $21(25.3)$ & $62(74.7)$ & 1.00 & & 1.00 & \\
\hline
\end{tabular}

\begin{tabular}{|c|c|c|c|c|c|c|c|}
\hline $\begin{array}{l}\text { Rarely } \\
\text { (once or } \\
\text { twice) }\end{array}$ & $98(24.9)$ & $29(29.6)$ & $69(70.4)$ & $\begin{array}{l}1.24(0.64- \\
2.40)\end{array}$ & 0.52 & $\begin{array}{l}2.11(0.91- \\
4.87)\end{array}$ & 0.080 \\
\hline $\begin{array}{l}\text { Sometimes } \\
(3-10 \\
\text { times) }\end{array}$ & $120(30.5)$ & $51(42.5)$ & $69(57.5)$ & $\begin{array}{l}2.18(1.18- \\
4.03)\end{array}$ & 0.013 & $\begin{array}{l}3.78(1.54- \\
9.24)\end{array}$ & 0.004 \\
\hline $\begin{array}{l}\text { Often } \\
\text { (more than }\end{array}$ & $92(23.4)$ & $25(27.2)$ & $67(72.8)$ & $\begin{array}{l}1.10(0.56- \\
2.16)\end{array}$ & 0.779 & $\begin{array}{l}3.12(1.1- \\
8.84)\end{array}$ & 0.032 \\
\hline
\end{tabular}

\begin{tabular}{|c|c|c|c|c|c|c|c|}
\hline $\begin{array}{l}\text { Rarely } \\
\text { (once or } \\
\text { twice) }\end{array}$ & $108(27.5)$ & $33(30.6)$ & $75(69.4)$ & $\begin{array}{l}0.76(0.39- \\
1.48)\end{array}$ & 0.419 & $\begin{array}{l}0.26(0.07- \\
0.96)\end{array}$ & 0.044 \\
\hline $\begin{array}{l}\text { Sometimes } \\
(3-10 \\
\text { times) }\end{array}$ & $175(44.5)$ & $62(35.4)$ & $113(64.6)$ & $\begin{array}{l}0.95(0.52- \\
1.74)\end{array}$ & 0.863 & $\begin{array}{l}0.1(0.02- \\
0.44)\end{array}$ & 0.002 \\
\hline $\begin{array}{l}\text { Often } \\
\text { (more than } \\
\text { 10) }\end{array}$ & $50(12.7)$ & $9(18.0)$ & $41(82.0)$ & $\begin{array}{l}0.38(0.16- \\
0.93)\end{array}$ & 0.033 & $\begin{array}{l}0.01(0- \\
0.09)\end{array}$ & 0.000 \\
\hline
\end{tabular}

\section{Discussion}

The general objective of this study was to assess the nutritional status of children aged 6-59 months in Jubek state, South Sudan. This study showed that the levels of stunting, wasting and underweight were high. One in three children were likely to be stunted (32.1\%), or wasted $(28.2 \%)$ or underweight $(32.3 \%)$. These results are comparable to the South Sudan Demographic and Health Survey report of 2006 which showed that $31 \%$ of the under five children were stunted, $23 \%$ wasted and $28 \%$ underweight (31). 
However, a study conducted in Jubek State South Sudan by Jessica Wude Murye in 2014 to determine the prevalence of iron deficiency anemia and associated factors in children aged 6-59 moths showed a lower prevalence of wasting at $10.5 \%$ and underweight at $15.4 \%$ (32). This implies that the nutritional status among children less than five years could have worsened during the study period for the following reasons; firstly, because of the famine that was reported in 2017 after Jessica's study. Secondly, this higher levels in our study, may also be blamed on the relatively good security status in Jubek state during study period compared to the rest of the country's states. A factor that has led to increase influx of families, internally displaced persons to the study area during data collection, increase in household sizes/dependents, and eventually increasing household energy requirements.

\section{Factors associated with stunting:}

In this study the multivariate analysis showed that factors including children older than one year, children who were having a symptom of loss of appetite in the past two weeks, eating from own plate, not consuming vitamin A rich vegetables and tubers and not consuming other vegetables other than leafy vegetables had significant association with stunting. It was also found that children from households with no latrine and were defecating in open space were more likely to be stunted. Although the overall household food insecurity was extremely high at $91.6 \%$, its association with childhood stunting was surprisingly not significant. The study also found that children who ate a limited variety of foods, and children with acute illness within two weeks were statically associated with stunting.

\section{Socio-demographic and economic status}

Children older than 12 months were 9.9 times more likely to be stunted compared to children who were aged less than 12 months. This finding was also found in other studies from the neighboring countries( 9 , 10). The most probable explanation would be that many children were no longer breast feeding above 12 months of age evidenced by a higher proportion of those who were not exclusively breastfeed at 6 months and the weaning diet being predominantly porridge. The odds of having a child with stunting from households who rented their houses, defecate in open spaces were higher than children from households who owned their houses, and who had flash toilet. This finding reflects the effect of socioeconomic inequalities as a key social determinant of health and child's nutritional status. This finding is in line with studies from Uganda and Kenya which found association between not having land, living in a temporally house with child's malnutrition, respectively (36).

\section{Child health factors}

The current study also found that children who had acute illness within two weeks of interview and who had particularly loss of appetite were more likely to be stunted. This could be due to the complex interaction between infection and malnutrition which results in reduced food intake, nutrient absorption, direct or catabolic nutrient losses, and increased metabolic requirements. A study found that that acute phase response and pro-inflammatory cytokines directly affect the bone remodeling required for longitudinal growth (41)(11). This study also found that children with no previous history of pneumonia 
were more likely to be stunted compared to those who had had pneumonia. This finding is not scientifically plausible. However, this may be explained by the prospective that most South Sudanese families have misconception and confusion between pneumonia and pulmonary tuberculosis which may have caused stigma and information bias.

\section{Nutrition and feeding practices}

In this study, children who were eating from their own plates were 2.7 times more likely to be stunted compared to those who were eating from the family pot. This could be attributed to many factors for example caretakers whose children were eating from their own plates might not have been adhering to the WHO recommendations regarding the practice of responsive feeding (feed infants directly and assist older children, feed slowly and patiently, encourage, talk to the child and maintain eye contact). Children eating from their own plates may not complete their rations of nutrients required to maintain growth. Studies found that children who feed themselves, eating with their hands rather than being fed by mothers were at higher risk of persistent diarrhea and malnutrition due to unhygienic behavior of hand washing (37). The current study also found that children who were weaned on milk were less likely to be stunted compared to those who were first introduced to porridge. This protective association was also observed in other studies which showed that the porridge was found to have anti nutrient inhibitor enzymes such as lectins, phytates which have negative effects on the linear growth $(37,38,(12,13)(11$, 12)12,13). Another study from Malawi also observed this finding by comparing stunting in children introduced on corn-Soy porridge versus milk and found that children complemented with milk were less likely to be stunted compared to those on soy based feeds(14).

\section{Food security}

The magnitude of food insecurity also explains the high prevalence of stunting since most households were food insecure. The main causes of stunting include inadequate nutrition to support the rapid growth and development of infants and young children, and frequent infections during early life. Although it was not significantly associated with stunting, a study by Wilna $\mathrm{H}$. from South Africa on Poverty, household food insecurity and nutrition concluded that caregivers from community with household food insecurity had changed their food consumption patterns to cope, resulting in compromised nutrition (15).

\section{Factors associated with wasting:}

This study revealed a strong association between male gender, households with two or more children aged zero to five years, not consuming vitamin A rich vegetable, diarrheal disease and households with water sources other than piped with wasting.

Results of the current study showed that female gender was protective against wasting. The reason could be due to the effect of cultural norms in most of the South Sudanese communities which favors female child to male child. This is in contrary to study from Asia by Kaneta K. on gender Inequality and Severe malnutrition among children in a remote rural area of Bangladesh that found that female children were 
more likely to be malnourished compared to male children (40). Studies have suggested that male children are generally more vulnerable to early childhood disease and health problems including malnutrition (16).

Diarrhea remains among the leading causes of mortality and morbidity in children aged less than five years in South Sudan. It indicates lack of basic sanitation and has a reciprocal relationship with malnutrition. In this study, children with diarrheal disease two weeks prior to the interview were 2.3 times wasted compared to those who had no diarrhea. The study also found that children from households using other sources of water other than piped water were threefold at risk of wasting. These findings were also reported in other studies (10).

\section{Factors associated with underweight:}

This study indicated that child age, not consuming vitamin A food, acute illness and children who didn't consume meat were more likely to be underweight. Although it is not a reliable indicator ,underweight (low weight for age) represents both chronic and acute malnutrition (17). The present study observed strong association between child's age with underweight. This finding was also reported in other studies by Pramod Singh: factors associated with underweight and stunting among children in rural Terai of eastern Nepal (18). Infections play a major role in the etiology of undernutrition because they result in increased needs and high energy expenditure, lower appetite, nutrient losses due to vomiting, diarrhea, poor digestion, mal-absorption and the utilization of nutrients and disruption of metabolic equilibrium (19). In this study, presence of an acute illness in the last two weeks prior to data collection was the contributing factor for all forms of malnutrition. Other studies have also confirmed this association $(20,21)$. The odds of a child being underweight were high among children who didn't consume meat. This finding was also reported study from Uganda in study done by Joyce K. Kikafunda ,which shows that, lack of meat consumption as a risk factor for low malnutrition (22).

Finding of this study should be cautiously interpreted since it encountered some limitations including; being conducted in a dry season when families were preparing for planting, the effect of seasonal variation could not be assessed since this was a cross sectional study. Also being a cross sectional study, the cause-effect relationship couldn't be conclusively assessed.

\section{Conclusion}

The findings of this study indicate that malnutrition is still a serious public health problem among children below five years of age in Jubek state, South Sudan. This study also concludes that factors including child's age, house ownership, absent of toilet at home, child illness and children eating from their own plate were associated with stunting. Whereas male gender, having more than two children aged less than five years, diarrheal illness and drinking non piped water were associated with wasting. Factors like child's age, eating from own plate and reported history of loss of appetite were cross-cutting between underweight and stunting 


\section{List Of Abbreviations And Acronyms}

ARI

HFIAS

HIV

HSDP

IYCF

Kgs

MRDT

MUAC

PI

SDs

SHHS

SOMREC

TB

UNICEF

WHO

MOH RSS
Acute respiratory infection

Household food insecurity access scale

Human Immunodeficiency Virus

Health sector development plan

Infant and young child feeding practice

kilograms

Malaria rapid diagnostic test

Mid upper arm circumference

Principle investigator

Standard Deviations

Sudan Household Health Survey

School of medicine research and ethics committee

Tuberculosis

United Nations International Children's Emergency Fund

World Health Organization

Ministry of Health Republic of South Sudan

\section{Declarations}

\section{Ethics Approval and consent to participate}

Ethics approval for this study and a request for waiver of obtaining informed consent were sought and granted by Makerere University School of Medicine Research and Ethics Committee. Ethics approval was also obtained from the MoH RSS Research Ethics Committee to conduct the study. A written informed consent/assent was sought from the caregiver followed by a full explanation of the study objectives, procedures, risks and benefits. Care givers were also informed that they had rights to participate and withdraw out of the study at any time. All the information was and will be kept confidential and used only for the purpose of the present study. 


\section{Consent to publish}

Not Applicable.

\section{Availability of data and materials}

The original data set will be availed by the corresponding author upon request.

\section{Competing interests}

The authors declare that they have no conflict of interest.

\section{Funding}

Mama- Baby Survival PLUSS through NORHED Projects fully funded this research from the design of the study and collection, analysis, and interpretation of data but not in writing the manuscript

\section{Authors' contributions}

MA, as corresponding author conceived the idea and applied for funding for this research. He led the data collection and the manuscript writing. Prof NG, was the main supervisor who has been involved in the whole process pertaining this work i.ie. drafting, funding, and substantively revised it. Dr. NBN, and Dr. $\mathrm{HC}$ supervised and guided the corresponding auther through the process of writing the manuscript, interpreting and analyzing the data.

\section{Acknowledgements}

Special thanks to my supervisors Prof Grace Ndeezi, Dr. Nicolette Nabukeera and Dr. Hassan Chollong for their guidance, mentorship, patience and continuing support throughout the phases of the development of this dissertation. I cannot thank you enough. To all the pediatricians in the Department of Pediatrics and Child Health, I am eternally indebted to you for your support, encouragement and immense contributions towards the success of this work and my personal growth. Finally, I thank the research assistants. I thank my Biostatistician without whom this work would not have been possible.

\section{Authors' information}

MAI, MBBS Juba University, MMed Pediatrics Makerere University. Lecturer at college of Medicine University of Juba, also currently works as a pediatrician at Nimule hospital Torit state South Sudan.

\section{References}

1. WHO. Maternal, newborn, child and adolescent health 2016 [cited 2016 3/9/2016]. Available from: http://www.who.int/entity/maternal_child_adolescent/about/en/. 
2. Bhutta ZA, Salam RA. Global nutrition epidemiology and trends. Annals of Nutrition and Metabolism. 2013;61(Suppl. 1):19-27.

3. Olwedo MA, Mworozi E, Bachou H, Orach CG. Factors associated with malnutrition among children in internally displaced person \'s camps, northern Uganda. African health sciences. 2009;8(4):244-52.

4. Tumwine J, A. O. Nutrition status of children in Kasese distric at the Uganda-Congo border. East African medical journal. 2002;2002,79(8):427-34.

5. UNICEF W, World Bank, UN-DESA Population Division. Levels and trends in child mortality 2013.

6. www.childrenofsouthsudan.info/unicef-south-sudan-situation-report-22-october-2015. UNICEF South Sudan Situation 22 October 2015.

7. Map JS.

8. Salvador Castell G, Pérez Rodrigo C, de la Cruz JN, Aranceta Bartrina J. Household food insecurity access scale (HFIAS). Nutricion hospitalaria. 2015;31(3).

9. Mengistu K, Alemu K, Destaw B. Prevalence of malnutrition and associated factors among children aged 6-59 months at Hidabu Abote District, North Shewa, Oromia Regional State. J nutr disorders ther. 2013;1:1-15.

10. Bloss E, Wainaina F, Bailey RC. Prevalence and Predictors of Underweight, Stunting, and Wasting among Children Aged 5 and Under in Western Kenya. Journal of Tropical Pediatrics. 2004;50(5):26070.

11. Stephensen CB. Burden of infection on growth failure. The Journal of nutrition. 1999;129(2):534S$8 \mathrm{~S}$.

12. Sarwar G. The protein digestibility-corrected amino acid score method overestimates quality of proteins containing antinutritional factors and of poorly digestible proteins supplemented with limiting amino acids in rats. The Journal of nutrition. 1997;127(5):758-64.

13. Hoppe C, Andersen GS, Jacobsen S, Mølgaard C, Friis H, Sangild PT, et al. The use of whey or skimmed milk powder in fortified blended foods for vulnerable groups. The Journal of nutrition. 2008;138(1):145S-61S.

14. Mangani C, Maleta K, Phuka J, Cheung YB, Thakwalakwa C, Dewey K, et al. Effect of complementary feeding with lipid-based nutrient supplements and corn-soy blend on the incidence of stunting and linear growth among 6-to 18-month-old infants and children in rural Malawi. Maternal \& child nutrition. 2015;11(S4):132-43.

15. Oldewage-Theron WH, Dicks EG, Napier CE. Poverty, household food insecurity and nutrition: Coping strategies in an informal settlement in the Vaal Triangle, South Africa. Public Health. 2006;120(9):795-804.

16. Kavosi E, Rostami ZH, Kavosi Z, Nasihatkon A, Moghadami M, Heidari M. Prevalence and determinants of under-nutrition among children under six: a cross-sectional survey in Fars province, Iran. International journal of health policy and management. 2014;3(2):71. 
17. Janevic T, Petrovic O, Bjelic I, Kubera A. Risk factors for childhood malnutrition in Roma settlements in Serbia. BMC public health. 2010;10(1):509.

18. Pramod Singh G, Nair M, Grubesic RB, Connell FA. Factors associated with underweight and stunting among children in rural Terai of eastern Nepal. Asia Pacific Journal of Public Health. 2009;21(2):14452.

19. Morris SS, Cogill B, Uauy R, Maternal, Group CUS. Effective international action against undernutrition: why has it proven so difficult and what can be done to accelerate progress? The Lancet. 2008;371(9612):608-21.

20. Teshome B, Kogi-Makau W, Getahun Z, Taye G. Magnitude and determinants of stunting in children underfive years of age in food surplus region of Ethiopia: the case of west gojam zone. Ethiopian Journal of Health Development. 2009;23(2).

21. Hien NN, Hoa NN. Nutritional status and determinants of malnutrition in children under three years of age in Nghean, Vietnam. Pak J Nutr. 2009;8(7):958-64.

22. Kikafunda JK, Walker AF, Collett D, Tumwine JK. Risk factors for early childhood malnutrition in Uganda. Pediatrics. 1998;102(4):e45-e.

\section{Figures}

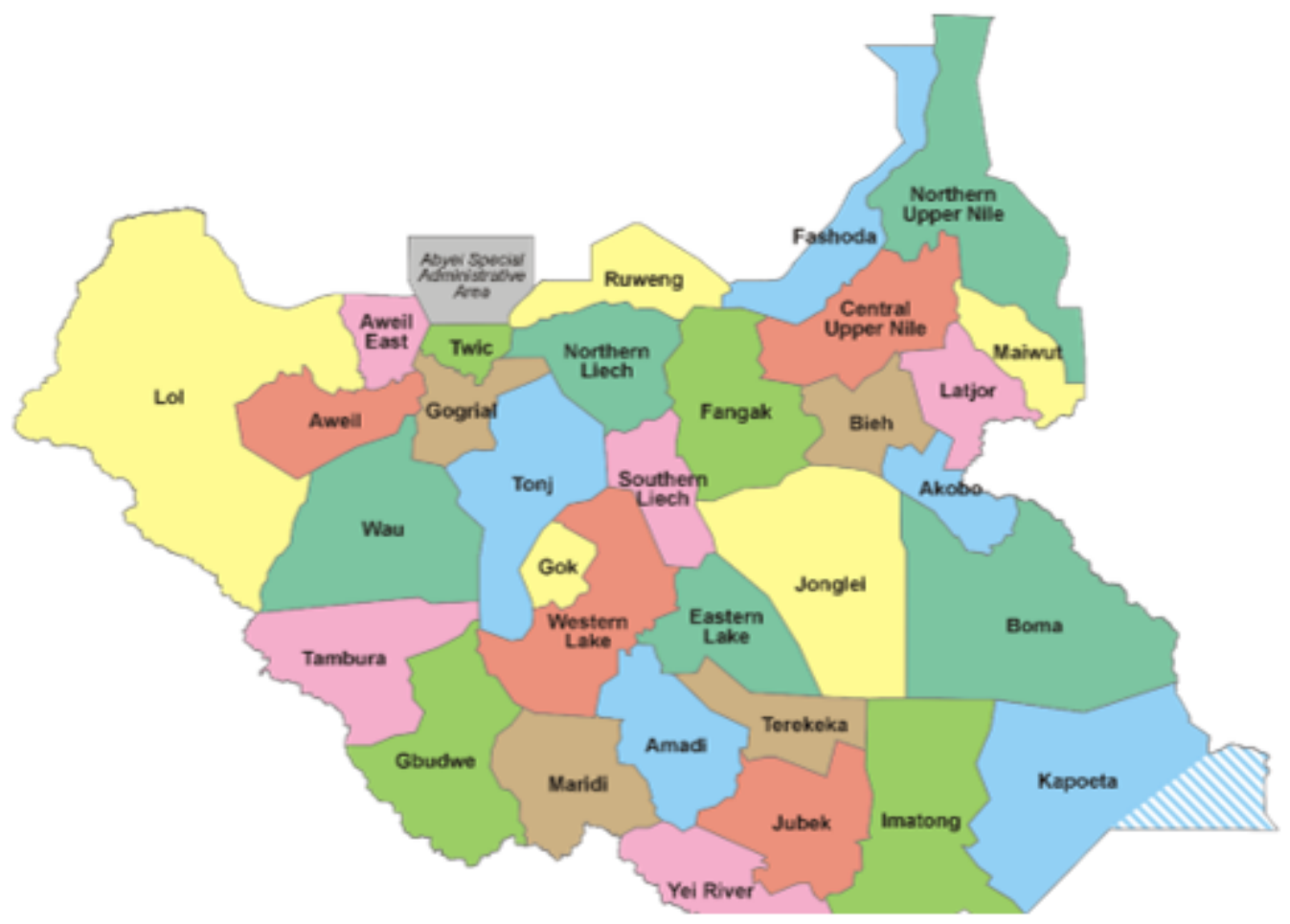

\section{Figure 1}

South Sudan Map 


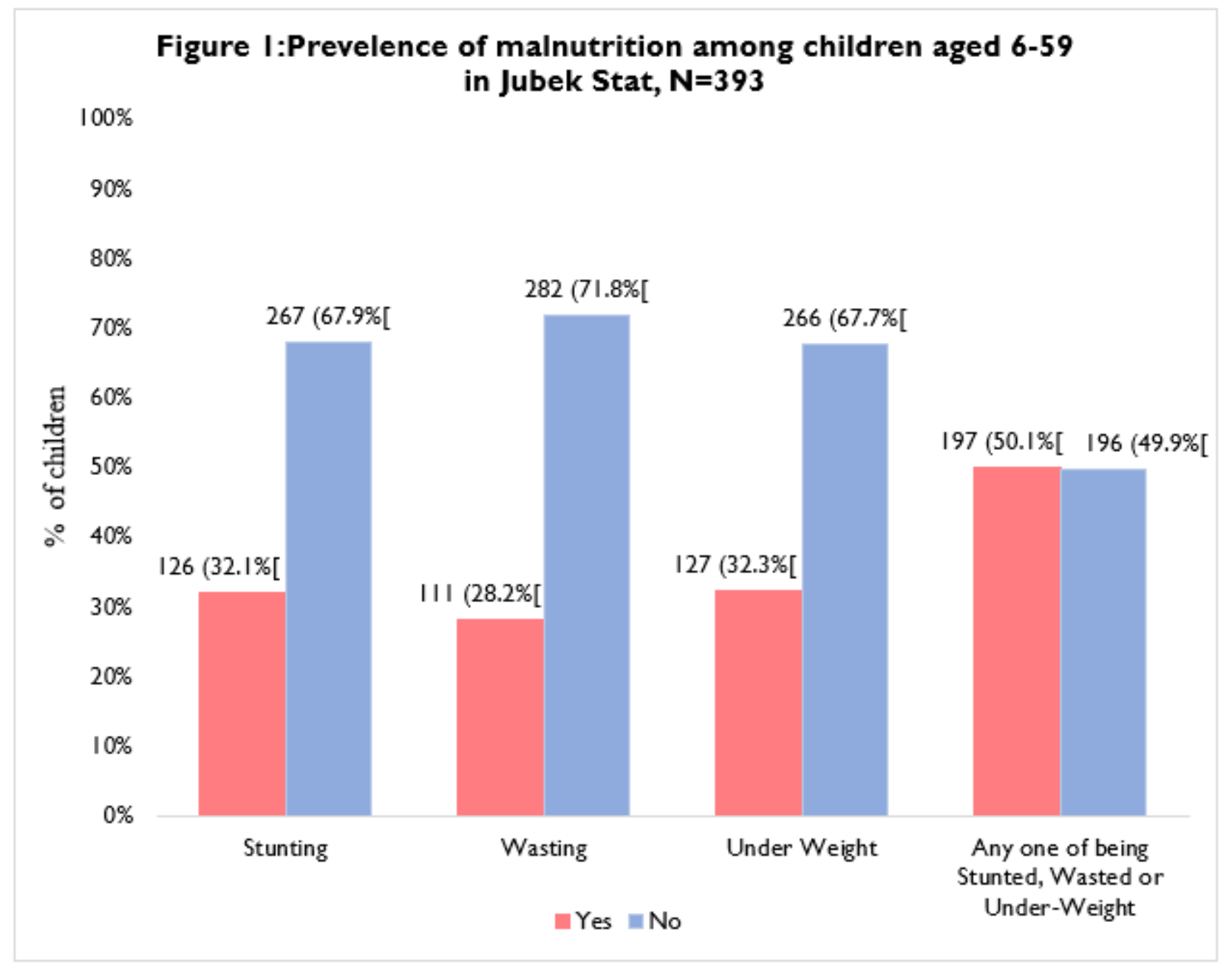

Figure 2

Prevelence of malnutrition among children aged 6-59 in Jubek Stat, $N=393$ 